\title{
An exploration study to detect important factors influencing on learning oriented customers
}

\author{
Naser Azad ${ }^{*}$ and Sima Zomorrodian
}

Department of Management and Accounting, Tehran South Branch, Islamic Azad University, Tehran, Iran

\section{H R O N I C L E A B S T R A C T}

Article history:

Received January 20, 2014

Accepted 30 August 2014

Available online

August 302014

Learning organizations

Learning management

Human resources management

\begin{abstract}
The recent advances in technology have increased learning channels in industry helping organizations remove the middle level management. This paper presents an empirical investigation to study the role of different factors influencing on learning oriented customers. The study designs a questionnaire and distributes it among 200 randomly selected regular customers of a chain store named Shahrvand located in city of Tehran, Iran. Cronbach alpha is equal to 0.935 , which is well above the minimum acceptable level. Using principle component analysis, the study has detected six factors including learning management, strategy, learning tools, learning approaches, human related factors and learning spirit.
\end{abstract}

\section{Introduction}

The recent advances in technology have increased learning channels in industry helping organizations remove the middle level management (Ratten, 2008; D'Amato \& Herzfeldt, 2008; Souchon et al., 2012). Gardiner (1999) presented a study in two large engineering firms trying to use a learning orientation and discussed a new sector-specific model of a learning orientation. The study highlighted a necessity for bigger evaluation of learning in organizations and a more holistic method to the implementation of learning initiatives. Coad and Berry (1998) stated that desirable leadership behavior for a learning organization is transformational and desirable follower behavior must include a learning orientation. Lee and Tsai (2005) investigated the impacts of business operation mode on market orientation, learning orientation and innovativeness. Paparoidamis (2005) investigated the relationship between learning orientation and leadership quality by investigating their effect on salespersons' performance. Mavondo et al. (2005) studied the relationship between learning orientation and market orientation by exploring the relationship with innovation, human resource practices and performance.

*Corresponding author.

E-mail addresses: N_azad@azad.ac.ir (N.Azad) 
McGuinness and Morgan (2005) studied the effect of market and learning orientation on strategy dynamics. Kropp et al. (2006) investigated entrepreneurial, market, and learning orientations and international entrepreneurial business venture (IEBV) performance in South African firms. They reported that IEBV performance was positively associated with the innovativeness component of an entrepreneurial orientation. Keskin (2006) studied market orientation, learning orientation, and innovation capabilities in SMEs. He reported that firm innovativeness positively influenced on firm performance and firm learning-orientation positively affected firm innovativeness. Kim (2007) investigated learning goal orientation, formal mentoring, and leadership competence in human resources development.

\section{The proposed study}

This paper presents an empirical investigation to study the role of different factors influencing on learning oriented customers. The study is concentrated on regular customers of a chain store named Shahrvand located in city of Tehran, Iran. The sample size is calculated as follows,

$$
N=Z_{\alpha / 2}^{2} \frac{p \times q}{e^{2}},
$$

where $N$ is the sample size, $p=1-q$ represents the probability, $z_{\alpha / 2}$ is CDF of normal distribution and finally $\varepsilon$ is the error term. For our study we assume $p=0.5, z_{\alpha / 2}=1.96$ and $e=0.05$, the number of sample size is calculated as $N=198$. The study desings a questionnaire in Likert scale, distributes 33 ones among some experts in order to validate the overal questionnaire. Cronbach alpha has been calculated as 0.935 , which is well above the minimum acceptable level. Therefore, we distribute 200 questionnaires among some randomly selected people who do regular purchase from this store. Table 1 shows the results of communalities.

Table 1

The summary of communalities

\begin{tabular}{cccccc}
\hline Variable & Initial & Extraction & Variable & Initial & Extraction \\
\hline VAR00001 & 1.000 & .676 & VAR00018 & 1.000 & .621 \\
VAR00002 & 1.000 & .745 & VAR00019 & 1.000 & .680 \\
VAR00003 & 1.000 & .615 & VAR00020 & 1.000 & .631 \\
VAR00004 & 1.000 & .626 & VAR00021 & 1.000 & .617 \\
VAR00005 & 1.000 & .726 & VAR00022 & 1.000 & .746 \\
VAR00006 & 1.000 & .752 & VAR00023 & 1.000 & .764 \\
VAR00007 & 1.000 & .555 & VAR00024 & 1.000 & .606 \\
VAR00008 & 1.000 & .660 & VAR00025 & 1.000 & .657 \\
VAR00009 & 1.000 & .761 & VAR00026 & 1.000 & .689 \\
VAR00010 & 1.000 & .675 & VAR00027 & 1.000 & .598 \\
VAR00011 & 1.000 & .665 & VAR00028 & 1.000 & .582 \\
VAR00012 & 1.000 & .736 & VAR00029 & 1.000 & .627 \\
VAR00013 & 1.000 & .671 & VAR00030 & 1.000 & .607 \\
VAR00014 & 1.000 & .626 & VAR00031 & 1.000 & .517 \\
VAR00015 & 1.000 & .681 & VAR00032 & 1.000 & .635 \\
VAR00016 & 1.000 & .512 & VAR00033 & 1.000 & .676 \\
VAR00017 & 1.000 & .577 & & & \\
\hline
\end{tabular}

As we can observe from the results of Table 1, all communalities are within acceptable levels. Table 2 demonstrates the results of principle component analysis. 
Table 2

The summary of principle component analysis

\begin{tabular}{|c|c|c|c|c|c|c|}
\hline \multirow[t]{2}{*}{ Component } & \multicolumn{3}{|c|}{ Initial Eigenvalues } & \multicolumn{3}{|c|}{ Rotation Sums of Squared Loadings } \\
\hline & Total & $\%$ of Variance & Cumulative \% & Total & $\%$ of Variance & Cumulative \% \\
\hline 1 & 5.728 & 17.357 & 17.357 & 2.240 & 6.789 & 6.789 \\
\hline 2 & 2.049 & 6.209 & 23.567 & 2.211 & 6.700 & 13.489 \\
\hline 3 & 1.920 & 5.820 & 29.386 & 2.045 & 6.196 & 19.685 \\
\hline 4 & 1.738 & 5.267 & 34.654 & 1.858 & 5.629 & 25.315 \\
\hline 5 & 1.575 & 4.772 & 39.426 & 1.748 & 5.297 & 30.612 \\
\hline 6 & 1.444 & 4.376 & 43.802 & 1.739 & 5.270 & 35.882 \\
\hline 7 & 1.380 & 4.182 & 47.984 & 1.681 & 5.094 & 40.976 \\
\hline 8 & 1.284 & 3.890 & 51.874 & 1.680 & 5.091 & 46.066 \\
\hline 9 & 1.190 & 3.605 & 55.480 & 1.662 & 5.036 & 51.102 \\
\hline 10 & 1.159 & 3.511 & 58.991 & 1.565 & 4.744 & 55.846 \\
\hline 11 & 1.027 & 3.112 & 62.103 & 1.552 & 4.703 & 60.549 \\
\hline 12 & 1.018 & 3.086 & 65.189 & 1.531 & 4.640 & 65.189 \\
\hline 13 & .912 & 2.765 & 67.953 & & & \\
\hline 14 & .881 & 2.670 & 70.623 & & & \\
\hline 15 & .800 & 2.424 & 73.047 & & & \\
\hline 16 & .779 & 2.362 & 75.409 & & & \\
\hline 17 & .734 & 2.223 & 77.632 & & & \\
\hline 18 & .689 & 2.087 & 79.719 & & & \\
\hline 19 & .677 & 2.050 & 81.770 & & & \\
\hline 20 & .647 & 1.960 & 83.730 & & & \\
\hline 21 & .602 & 1.824 & 85.553 & & & \\
\hline 22 & .580 & 1.758 & 87.311 & & & \\
\hline 23 & .543 & 1.647 & 88.958 & & & \\
\hline 24 & .492 & 1.490 & 90.448 & & & \\
\hline 25 & .484 & 1.467 & 91.915 & & & \\
\hline 26 & .429 & 1.300 & 93.215 & & & \\
\hline 27 & .395 & 1.196 & 94.410 & & & \\
\hline 28 & .358 & 1.085 & 95.496 & & & \\
\hline 29 & .350 & 1.061 & 96.557 & & & \\
\hline 30 & .340 & 1.031 & 97.587 & & & \\
\hline 31 & .292 & .884 & 98.472 & & & \\
\hline 32 & .270 & .818 & 99.290 & & & \\
\hline 33 & .234 & .710 & 100.000 & & & \\
\hline
\end{tabular}

According to the results of Table 2, there are 12 influencing factors and we use varimax rotation technique to extract the important components. In addition, Scree plot has been used to extract the important factors show in Fig. 1 as follows,

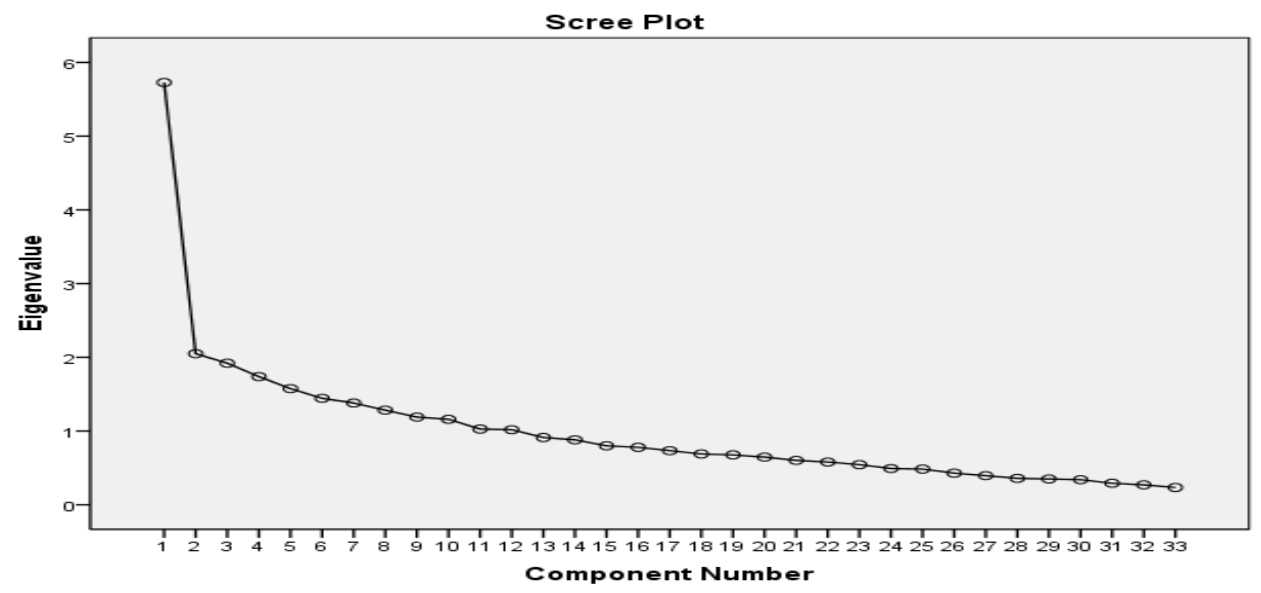

Fig. 1. The summary of Scree plot 
1924

According to the results of Fig. 1, there are six factors influencing on learning oriented customers. Table 3 shows the results of our investigation.

Table 3

The summary of principal component analysis using Varimax rotation

\begin{tabular}{|c|c|c|c|c|c|c|c|c|c|c|c|c|}
\hline & \multicolumn{12}{|c|}{ Component } \\
\hline & 1 & 2 & 3 & 4 & 5 & 6 & 7 & 8 & 9 & 10 & 11 & 12 \\
\hline VAR000 & & & .533 & & & & & & & & & .379 \\
\hline VAR000 & & & .839 & & & & & & & & & \\
\hline VAR000 & & & .706 & & & & & & & & & \\
\hline VAR000 & & & & & & & & .655 & & & & \\
\hline VAR000 & & & & & & & & .591 & & .462 & & \\
\hline VAR000 & & & & & & & & & & .837 & & \\
\hline VAR000 & & & & & & & & & & & & .679 \\
\hline VAR000 & & & & & & & & & .653 & & & .395 \\
\hline VAR000 & & & & & & & & & & & .779 & \\
\hline VAR000 & & & & & & & & & & & .704 & \\
\hline VAR000 & .38 & & & & & & .499 & & .342 & & & \\
\hline VAR000 & & .448 & & & & & .375 & & & .512 & & \\
\hline VAR000 & & .563 & & .423 & & & & & & & & \\
\hline VAR000 & & .332 & & & & .556 & & & & & & \\
\hline VAR000 & .34 & .414 & & & & & & & & & & \\
\hline VAR000 & .52 & & & & & & & & & & & \\
\hline VAR000 & & & & & & & & & .527 & & & \\
\hline VAR000 & & .472 & & & & & & & & & & \\
\hline VAR000 & & & & & & & .781 & & & & & \\
\hline VAR000 & & & .340 & & & & .575 & & & & & \\
\hline VAR000 & & & & & .681 & & & & & & & \\
\hline VAR000 & & & & & .761 & & & & & & & \\
\hline VAR000 & .59 & & & & .352 & & & .400 & & & & \\
\hline VAR000 & .72 & & & & & & & & & & & \\
\hline VAR000 & .47 & & & & & .460 & & & & & & \\
\hline VAR000 & & & & & & & & & .633 & & & \\
\hline VAR000 & & .699 & & & & & & & & & & \\
\hline VAR000 & & .382 & & & .475 & & & & & & & \\
\hline VAR000 & & & & & & .733 & & & & & & \\
\hline VAR000 & & & & .474 & & & & .419 & & & & \\
\hline VAR000 & .34 & & & & & & & & & & & \\
\hline VAR000 & & & & .435 & & & & & & & & .499 \\
\hline VAR000 & & & & .768 & & & & & & & & \\
\hline
\end{tabular}

\section{The results}

According to the results of Table 3, there are six factors associated with the proposed study of this paper including learning management, strategy, learning tools, learning approaches, human related factors and learning spirit.

\subsection{Learning management}

Learning management is the first factor in this study and Table 3 shows details of sub-factors. 
Table 3

The summary of the components associated with learning management

\begin{tabular}{lcccc}
\hline Sub-component & Factor loading & Eigenvalues & \% of variance & Accumulated \\
\hline Effective leadership & 0.528 & & & \\
Top management support & 0.728 & 2.240 & 6.789 & 6.789 \\
Educational plan & 0.590 & & & \\
Reward paid to leaners & 0.474 & & & \\
Open management & 0.345 & & & \\
\hline
\end{tabular}

As we can observe from the results of Table 3, top management support is number one factor influencing on learning management followed by educational plan, effective leadership, reward paid to learners and open management.

\subsection{Strategy}

Strategy is the second factor in this study and Table 4 presents details of sub-factors.

\section{Table 4}

The summary of the components associated with strategy

\begin{tabular}{lrccc}
\hline Sub-component & Factor loading & Eigenvalues & \% of variance & Accumulated \\
\hline Common outlook & 0.563 & & & \\
Relationship with world & 0.414 & & & \\
Market orientation & 0.472 & & & \\
Group decision making & 0.699 & 2.211 & 13.489 & 6.700 \\
\hline
\end{tabular}

According to the results of Table 4, group decision making is the most important factor influencing on strategy followed by common outlook, market orientation and relationship with world.

\subsection{Learning tools}

Learning tools are considered as the third important factor in this study and Table 5 provides details of three sub-factors.

Table 5

The summary of the components on learning tools

\begin{tabular}{lrccc}
\hline Sub-component & Factor loading & Eigenvalues & \% of variance & Accumulated \\
\hline Sharing effective information & 0.523 & & & \\
Employee ethics & 0.839 & 2.045 & 19.685 & 6.196 \\
Advanced technology & 0.706 & & & \\
\hline
\end{tabular}

According to the results of Table 5, employee ethics is the most important factors influencing learning tools followed by advanced technology and sharing effective information.

\subsection{Learning approaches}

Learning approaches are considered as the fourth important factor in this study and Table 6 shows details of three sub-factors.

\section{Table 6}

The summary of the components on learning approaches

\begin{tabular}{lcccc}
\hline Sub-component & Factor loading & Eigenvalues & \% of variance & Accumulated \\
\hline Work engagement & 0.681 & & & \\
Ideas & 0.761 & 1.858 & 25.315 & 5.629 \\
Critical discussions & 0.475 & & & \\
\hline
\end{tabular}


According to the results of Table 6, having perceptional ideas is number one important factor influencing on learning approaches followed by work engagement and critical discussions.

\subsection{Human factors}

Human factors are considered as the fifth important factor in this study and Table 7 demonstrates details of three sub-factors.

\section{Table 7}

The summary of the components on human factors

\begin{tabular}{lcccc}
\hline Sub-component & Factor loading & Eigenvalues & \% of variance & Accumulated \\
\hline Learning commitment & 0.499 & & & \\
Employee perception & 0.781 & 1.748 & 30.612 & 5.297 \\
Employee skills & 0.575 & & & \\
\hline
\end{tabular}

According to the results of Table 7, having perceptional ideas is number one important factor influencing on learning approaches followed by work communications and critical discussions.

\subsection{Learning spirit}

Learning spirit is the last important factor in this study and Table 8 shows details of three sub-factors.

\section{Table 8}

The summary of the components on learning spirit

\begin{tabular}{lcccc}
\hline Sub-component & Factor loading & Eigenvalues & \% of variance & Accumulated \\
\hline Choosing challenging tasks & 0.653 & 1.739 & 35.882 & 5.270 \\
Job performance & 0.527 & & & \\
Risk acceptance & 0.633 & & & \\
\hline
\end{tabular}

According to the results of Table 8, Choosing challenging tasks is the most important factor followed by risk acceptance and job performance.

\section{Discussion and conclusion}

In this paper, we have presented an empirical investigation to study the role of different factors influencing on learning oriented customers. The study has implemented factor analysis and extracted six factors influencing on learning oriented customers. In terms of learning management, top management support is number one factor influencing on learning management followed by educational plan, effective leadership, reward paid to learners and open management. Strategy is the second factor where group decision making is the most important factor influencing on strategy followed by common outlook, market orientation and relationship with world. Learning tools are considered as the third important factor where employee ethics is the most important factors influencing learning tools followed by advanced technology and sharing effective information. Learning approaches are considered as the fourth important factor in this study where having perceptional ideas is number one important factor influencing on learning approaches followed by work engagement and critical discussions. Human factors are considered as the fifth important factor where having perceptional ideas is number one important factor influencing on learning approaches followed by work communications and critical discussions. Finally, Learning spirit is the last important factor in this study with three factors where choosing challenging tasks is the most important factor followed by risk acceptance and job performance. 
The results of our study are consistent with findings of Chughtai and Buckley (2011) in terms of work engagement. The results are also consistent with findings of Wu and Lin (2013) and Lin et al. (2008). As stated by Ratten (2008), there has been a shift in many business organizations to create a learning organization in which productivity and effectiveness can be enhanced. Learning organizations are those in which people are continually expanding their knowledge base to nurture new techniques of thinking. Learning orientation states a core dimension in organizational learning. Therefore, the attitude an organization has towards the necessity of learning is its learning orientation and this is reflected in values routinely associated with learning.

\section{Acknowledgement}

The authors would like to thank the anonymous referees for constructive comments on earlier version of this paper.

\section{References}

Coad, A. F., \& Berry, A. J. (1998). Transformational leadership and learning orientation. Leadership \& Organization Development Journal, 19(3), 164-172.

Chughtai, A. A., \& Buckley, F. (2011). Work engagement: antecedents, the mediating role of learning goal orientation and job performance. Career Development International, 16(7), 684-705.

D'Amato, A., \& Herzfeldt, R. (2008). Learning orientation, organizational commitment and talent retention across generations: A study of European managers. Journal of Managerial Psychology, 23(8), 929-953.

Gardiner, P. (1999). Soaring to new heights with learning orientated companies. Journal of Workplace Learning, 11(7), 255-265.

Herhausen, D., \& Schögel, M. (2013). Profiting from customer relationship management: The overlooked role of generative learning orientation. Management Decision, 51(8), 1678-1700.

Keskin, H. (2006). Market orientation, learning orientation, and innovation capabilities in SMEs: An extended model. European Journal of Innovation Management, 9(4), 396-417.

Kim, S. (2007). Learning goal orientation, formal mentoring, and leadership competence in HRD: a conceptual model. Journal of European Industrial Training, 31(3), 181-194.

Kropp, F., Lindsay, N. J., \& Shoham, A. (2006). Entrepreneurial, market, and learning orientations and international entrepreneurial business venture performance in South African firms. International Marketing Review, 23(5), 504-523.

Lee, T. S., \& Tsai, H. J. (2005). The effects of business operation mode on market orientation, learning orientation and innovativeness. Industrial Management \& Data Systems, 105(3), 325-348.

Lin, C. H., Peng, C. H., \& Kao, D. T. (2008). The innovativeness effect of market orientation and learning orientation on business performance. International Journal of Manpower, 29(8), 752-772.

Mavondo, F. T., Chimhanzi, J., \& Stewart, J. (2005). Learning orientation and market orientation: relationship with innovation, human resource practices and performance. European Journal of Marketing, 39(11/12), 1235-1263.

McGuinness, T., \& Morgan, R. E. (2005). The effect of market and learning orientation on strategy dynamics: The contributing effect of organisational change capability. European Journal of Marketing, 39(11/12), 1306-1326.

Paparoidamis, N. G. (2005). Learning orientation and leadership quality: their impact on salespersons' performance. Management Decision, 43(7/8), 1054-1063.

Ratten, V. (2008). Organizational learning orientation-how can it foster alliance relationships?. Development and learning in organizations: an international journal, 22(1), 20-21.

Souchon, A. L., Sy-Changco, J. A., \& Dewsnap, B. (2012). Learning orientation in export functions: impact on export growth. International Marketing Review,29(2), 175-202. 
1928

Wu, L. W., \& Lin, J. R. (2013). Knowledge sharing and knowledge effectiveness: learning orientation and co-production in the contingency model of tacit knowledge. Journal of Business \& Industrial Marketing, 28(8), 672-686. 